\title{
A comparative study of two separate analytical techniques for the simultaneous determination of diclofenac sodium and diacerein from combined dosage form
}

\author{
Sanhita Basu Mallick¹, Helen Chattopadhyay ${ }^{1}$, Amit Kumar De², Sriparna Datta1,*
}

${ }^{1}$ Department of Chemical Technology, Division of Pharmaceuticals and Fine Chemical Technology, University College of Science and Technology, University of Calcutta, West Bengal, India, ${ }^{2}$ Dey's Medical Stores (Mfg.) Ltd., West Bengal, India

\begin{abstract}
Diclofenac sodium (DS) and diacerein (DC) have emerged as a potential combination therapy for the treatment of knee osteoarthritis. Therefore a validated analytical method is essential for the simultaneous estimation of both from combined dosage form. A ratio derivative spectrophotometric and a chromatographic technique have been developed for the simultaneous determination of DS and DC. The quantification was done at $263.00 \mathrm{~nm}$ for DC and $304.50 \mathrm{~nm}$ for DS in the first method, whereas 257 $\mathrm{nm}$ for DC and at $274 \mathrm{~nm}$ for DS for LC-DAD analysis in chromatographic method using acetate buffer and methanol as the mobile phase at a flow-rate $0.50 \mathrm{~mL} / \mathrm{min}$. Both of these methods are found to be linear in the concentration range under study with $\mathrm{r}^{2}$ value 0.999 and 0.996 for DS and DC respectively in ratio derivative spectroscopy and 0.998 and 0.999 for DS and DC respectively in LC-DAD study. Both of these methods are found to be accurate and precise, though greater robustness and precision is observed with chromatographic analysis over the ratio derivative spectroscopy. Statistically there was no significant difference between proposed ratio derivative spectrophotometric and LC-DAD methods.
\end{abstract}

Uniterms: Diacerein/comparative study. Diclofenac sodium/comparative study. High Pressure Liquid Chromatography. LC-DAD. Ratio derivative spectroscopy/validation

\section{INTRODUCTION}

Diacerein (DC), chemically 4,5-diacetoxy-9,10dihydro-9,10-dioxo-2- anthracenecarboxylic acid (Figure 1A), is an anti-osteoarthritic (Bartelsyz et al., 2010; Fidelix et al., 2014) drug usually prescribed for the treatment of symptomatic osteoarthritis of knee (Louthrenoo et al., 2007; Zheng et al., 2006). It is a purified anthraquinone and on absorption it is entirely transformed into rhein, an active metabolite found in plasma and synovial fluid. DC defines a new class of anti-osteoarthritic drug known as "disease modifying osteoarthritis drug" (DMOAD) or "chemoprotective agent" (Verbruggen, 2006; Pelletier, Martel-Pelletier, 2007). It is found to have novel anti-inflammatory properties different from classical nonsteroidal anti-inflammatory agents that support its use

\footnotetext{
*Correspondence: Sriparna Datta. Department of Chemical Technology. Division of Pharmaceuticals and Fine Chemical Technology. University College of Science and Technology. University of Calcutta. 92, A. P. C. Road, Kolkata, 700009 - West Bengal, India. E.mail: sriparnadatta2014@gmail.com, basumallick.sanhita919@gmail.com
}

in combination with nonsteroidal anti-inflammatory drugs (NSAID) for the treatment of osteoarthritis including rheumatoid osteoarthritis (Tamura et al., 2002). Recently it has been found to reduce visceral pain through inhibition of glutamatergic neurotransmission and cytokine signaling in mice (Gadotti et al., 2012).<smiles>CC(=O)CC1=CC(C(=O)O)=CC2C(=O)c3cccc(OC(C)=O)c3C(=O)C12</smiles>

(B)<smiles>O=C(Cc1ccccc1Nc1c(Cl)cccc1Cl)O[Na]</smiles>

FIGURE 1 - Chemical structure of diacerein (A) and diclofenac sodium (B).

Diclofenac sodium (DS) chemically sodium salt of 2-(2-(2,6-dichlorophenylamino)phenyl) acetic acid (Figure 1B), is a NSAID commonly prescribed for the relief of musculoskeletal disorders like joint pains, osteoarthritis 
and rheumatoid arthritis, inflammations, soft tissue disorders like sprains and several other pathophysiological conditions like acute gout, dysmenorrhea, migraine and even after certain surgical procedures (Zhang et al., 2014).

A recent report presents that the use of DC as an adjuvant to DS improves the therapeutic profile in osteoarthritic knee compared to DS alone (Singh, Sharma, Rai, 2012). Thus a combination of these two drugs forms a newer therapeutic regimen. Here in lies the need for the development of validated and sensitive analytical procedures for the simultaneous estimation of both DC and DS from such formulations.

The ratio derivative spectrophotometry (RDS) is a good analytical technique of great utility for extracting quantitative information from spectra of unresolved bands. In this RDS method the zero-order spectrum for a mixture is divided by the divisor standard spectra of each analyte followed by derivatization and hence the spectrum becomes independent of the other analyte concentration. The use of standardized spectra as divisors minimizes experimental errors and background noise. Easy measurements of separate peaks, higher values of the analytical signals are advantages of ratio derivative spectrophotometry. The presence of a lot of maxima and minima in ratio derivative spectra seems to be advantageous for the method, since these wavelengths give an opportunity for the determination of these compounds in the presence of other active compounds and excipients that may interfere.

High Pressure Liquid Chromatography (HPLC) is used in analytical chemistry or biochemistry to separate chemical compounds in mixtures for analysis or purification or quantification from a binary mixture. In this method the sample mixture is pressurized through a column filled with a solid adsorbent material, where each component in the sample interacts slightly differently with the adsorbent material, causing different flow rates for the different components and leading to the separation of the components as they flow out the column.

The review of the literature showed the presence of both spectrophotometric methods (Baghel, Dhiman, 2012; Nebsen et al., 2011; Pandey et al., 2012; Sivakumar et al., 2010) and chromatographic techniques (Ali et al., 2014; Ashok et al., 2009; Hamrapurkar et al., 2011; Patel et al., 2014; Sivakumar et al., 2010) for the estimation of DC from different formulations in presence of NSAIDs (Baghel, Dhiman, 2012), impurities (Ashok et al., 2009) and its corresponding metabolites from human serum (Ojha, Rathod, Padh, 2009). For the quantification of DS the pharmacopoeias present its non-aqueous titration in bulk forms and chromatographic procedures for various formulations (Dahivelkar et al., 2012). Other techniques include mainly spectrophotometric (Botello, PerezCaballero, 1995) and chromatographic procedures (AbdelHamid, Novotny, Hamza, 2001; Carreira et al., 1995; Ji, Zhan, 2000; Kaale et al., 2013; Thongchai et al., 2006) for analyzing the drugs individually.

However, extensive literature survey fails to present a rapid and selective spectroscopic analysis and chromatographic procedure for the simultaneous estimation of both these drugs from their combined dosage form. In the current study we present a simple, rapid, sensitive and validated spectroscopic method and a precise and validated chromatographic procedure based on LC-DAD technique for the estimation of both of these drugs in combined dosage from.

\section{MATERIAL AND METHODS}

\section{Material}

Diacerein (DC) was procured from Biogen Extracts Pvt. Ltd. (Bangalore, India) and diclofenac sodium (DS) was obtained as a gift sample from Dey's Medical Stores (Mfg.) Ltd. (Kolkata, India), Carbopol 934 (CDH) and triethanolamine (Merck) were purchased from local supplier. HPLC grade solvents like acetonitrile, methanol and water were purchased from Spectrochem India Ltd. All other salts and reagents were of guaranteed reagent grade and were purchased from Merck India Ltd. A C18 column $250 \mathrm{~mm}$ x $4.6 \mathrm{~mm}$ (Atlantis T3) was purchased from Water's Corporation (Millford, USA).

\section{Methods}

\section{Preparation of drug loaded transdermal gel}

The gel was prepared by dispersing $500 \mathrm{mg}$ of carbopol in definite amount of water very slowly with constant stirring. Then drug solution $(3.5 \mathrm{mg} / \mathrm{mL}$ of each in water) was added, followed by $2.5 \mathrm{~g}$ chloroform and distilled water to make the $25 \mathrm{~g}$ gel. The $\mathrm{pH}$ of the gel was brought to skin $\mathrm{pH}$ by adding $500 \mathrm{mg}$ triethanolamine. During $\mathrm{pH}$ adjustment, the mixture was stirred gently until the formation of homogeneous gel. The product was allowed to stand for 24 hours at room temperature before further studies (Karade et al., 2012).

\section{Procedure for ratio derivative spectroscopy}

A series of solutions in the concentration range $1 \mu \mathrm{g} / \mathrm{mL}$ to $10 \mu \mathrm{g} / \mathrm{mL}$ were obtained from respective stock solutions prepared in phosphate buffer $\mathrm{pH}$ 7.4. The absorption spectra were recorded between $200 \mathrm{~nm}$ to 600 
$\mathrm{nm}$ for standard and sample solutions against phosphate buffer (pH 7.4) as blank.

For sample solution, $1.0 \mathrm{~g}$ of the transdermal gel preparation was accurately weighed and transferred to a $50 \mathrm{ml}$ volumetric flask. $30 \mathrm{ml}$ of the buffer $\mathrm{pH} 7.4$ and 5 $\mathrm{mL}$ of methanol were added and the mass was sonicated for $1 \mathrm{hr}$, allowed to cool to room temperature and the final volume was made up with the buffer. It was centrifuged at $8000 \mathrm{rpm}$ for 25 minutes and the supernatant was diluted suitably to obtain a final concentration of $20 \mu \mathrm{g} / \mathrm{mL}$ for both DC and DS.

A study of variables like concentration of the standard spectrum divisor, number of points for the smoothing function and $\Delta \lambda$ were necessary for the simultaneous determination of DS and DC using first derivative ratio spectroscopy in order to optimize the signal of the ratio derivative spectra with good selectivity and higher sensitivity (Rote, Bari, 2009). Concentrations of $5 \mu \mathrm{g} / \mathrm{mL}$ of DC (DC5) and $6 \mu \mathrm{g} / \mathrm{ml}$ of DS (DS6) were selected as divisor concentration. The divisor concentration was chosen to minimize the background noise and experimental error. The saved spectrums of DC were divided with spectra of selected DS divisor spectra to get ratio spectra of DC and that of DS with DC divisor spectra to get the ratio spectra of DS. A $\Delta \lambda=5$ was chosen as optimum to minimize the background noise. The first order derivative of all the ratio spectra of DC and DS were done with $\Delta \lambda=5$.

RDS analysis was done using UV 1800 spectrophotometer (Shimadzu Corporation, Kyoto, Japan) and UV Probe Software, Version 2.42 (Shimadzu Corporation, Kyoto, Japan).

\section{Procedure forLC-DAD analysis}

DC and DS (1000 $\mu \mathrm{g} / \mathrm{mL})$ stock solutions were prepared by dissolving each working standard having known purity in $25 \mathrm{ml}$ of mobile phase. Different dilutions of these stock solutions were taken for preparation of linearity curve and working standard solutions for the purpose of validation.

For sample solution, $1.0 \mathrm{~g}$ of the prepared transdermal gel was carefully weighed and transferred to a $50 \mathrm{ml}$ volumetric flask. $35 \mathrm{~mL}$ of the mobile phase were added and sonicated for $1 \mathrm{hr}$, allowed to cool to room temperature and finally the volume was made up to $50 \mathrm{~mL}$. The final solution was centrifuged at $8000 \mathrm{rpm}$ for 25 minutes and supernatant was diluted properly to obtain a final solution having a concentration of $20 \mu \mathrm{g} / \mathrm{mL}$ of each, DC and DS.

The mobile phase was a mixture of $35 \%$ of $0.2 \mathrm{M}$ sodium acetate solution and $65 \%$ methanol at a flow rate of $0.50 \mathrm{~mL}$ per minute. The mobile phase and samples were filtered through $0.2 \mu \mathrm{m}$ membrane filter before each use. DC and DS concentrations were determined using the external standard calibration curve.

HPLC was performed by using Waters high pressure gradient HPLC module consisting of two Waters 515 pumps (Milfold, MA, USA) and 2996 PDA detector (Milfold, MA, USA). The data analysis and procurement were carried out using Waters Empower 2 software (Milfold, MA, USA). The column Atlantis T3 C18 (particle size $5 \mu \mathrm{m}, 4.6 \mathrm{~mm}$ internal diameter $\times 250 \mathrm{~mm}$ length) was used for the separation purpose and kept at room temperature using the detection wavelength $257 \mathrm{~nm}$ for DC and $274 \mathrm{~nm}$ for DS.

\section{Method validation}

The analytical method was validated as per ICH guidelines. The studied parameters were specificity, accuracy, precision, linearity, range, robustness and system suitability studies. The linearity of the method was established by analyzing standard solutions in triplicate.

To ensure reliability and accuracy of the proposed method, recovery studies were carried out by mixing a known quantity of the standard solution with the preanalyzed samples at three different levels $(80 \%, 100 \%$ and $120 \%$ of assay value) and were reanalyzed using the proposed method.

Precision of the method was measured on the basis of repeatability. For LC-DAD method the repeatability was measured on the basis of six replicate injections of the $20 \mu \mathrm{g} / \mathrm{ml}$ of each (DC and DS) solutions keeping the concentration of one component fixed at each concentration of the sample on the same day. The intra-day precision was calculated using six injections at the higher concentration on the same day. This study was repeated on three consecutive days to obtain the inter-day precision. The intermediate precision was obtained by triplicate injection of the sample solution on three different days.

The RDS method followed the same protocol mentioned for the LC-DAD analysis. For RDS the scanning range for the experimental solutions was 200 $600 \mathrm{~nm}$.

The limit of detection (LOD) and the limit of quantitation (LOQ) were determined using the equations presented as follows.

$$
\mathrm{LOD}=\frac{(3.3 \times \sigma)}{S} ; \mathrm{LOQ}=\frac{(10 \times \sigma)}{S}
$$

where denotes standard deviation of Y-intercepts, and S denotes slope of the linearity curve

The robustness of the LC-DAD method was determined by making slight changes in the chromatographic conditions. The parameter Specificity 
helps to measure accurately the analyte signal in presence of the potent excipients in formulation. The blank gel solution was used as placebo solution for this purpose and was analyzed by both of the proposed methods.

\section{Statistical Analysis}

The statistical analysis was carried out using Sigma Plot 10.0 (SSPS Inc., USA) and Microsoft Office Excel 2010. Each analysis was carried out in three replicates.

\section{RESULTS AND DISCUSSION}

\section{Ratio Derivative Spectrum analysis}

In RDS both, the standard and the sample solutions were scanned between $200 \mathrm{~nm}$ to $600 \mathrm{~nm}$. The absorbance maxima of zero order spectrums for DC and DS were observed at $258 \mathrm{~nm}$ and at $275 \mathrm{~nm}$ respectively. The absorption spectra of DS and DC presented strong overlapping over the range of $250 \mathrm{~nm}-300 \mathrm{~nm}$ (Figure 2). The zero-order spectrum of the mixture provides accurate quantification of DC at $258 \mathrm{~nm}$ only from the mixture, but not DS. In order to improve accuracy in quantification of $\mathrm{DS}$, ratio derivative analysis was carried out.

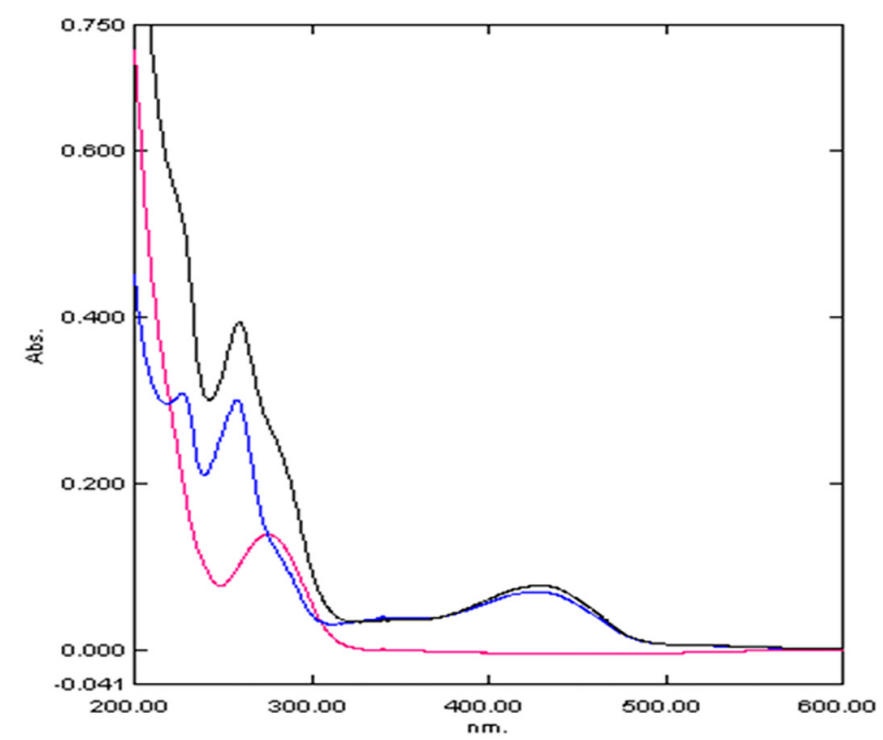

FIGURE 2 - Zero order spectrum of DC (blue), DS (red) and mixture of DC and DS (black).

The concentrations of the drugs were calculated from their corresponding regression equations (Equations $1,2)$ measuring the intensity of the signals of the ratio derivative spectrum (Figure 3 and 4). Wavelength 304.50 $\mathrm{nm}$ was selected for the quantification of DS and 263.00 nmwas selected for the quantification of DC in formulation containing both (Figure 5 and 6). Measured analytical signals at these wavelengths were found to be proportional to the concentrations of these drugs.

$$
\begin{aligned}
& y=1.965 x+0.156 \text { for } D S \text { Equation } 1 \\
& y=3.054 x+0.464 \text { for } D C \text { Equation } 2
\end{aligned}
$$

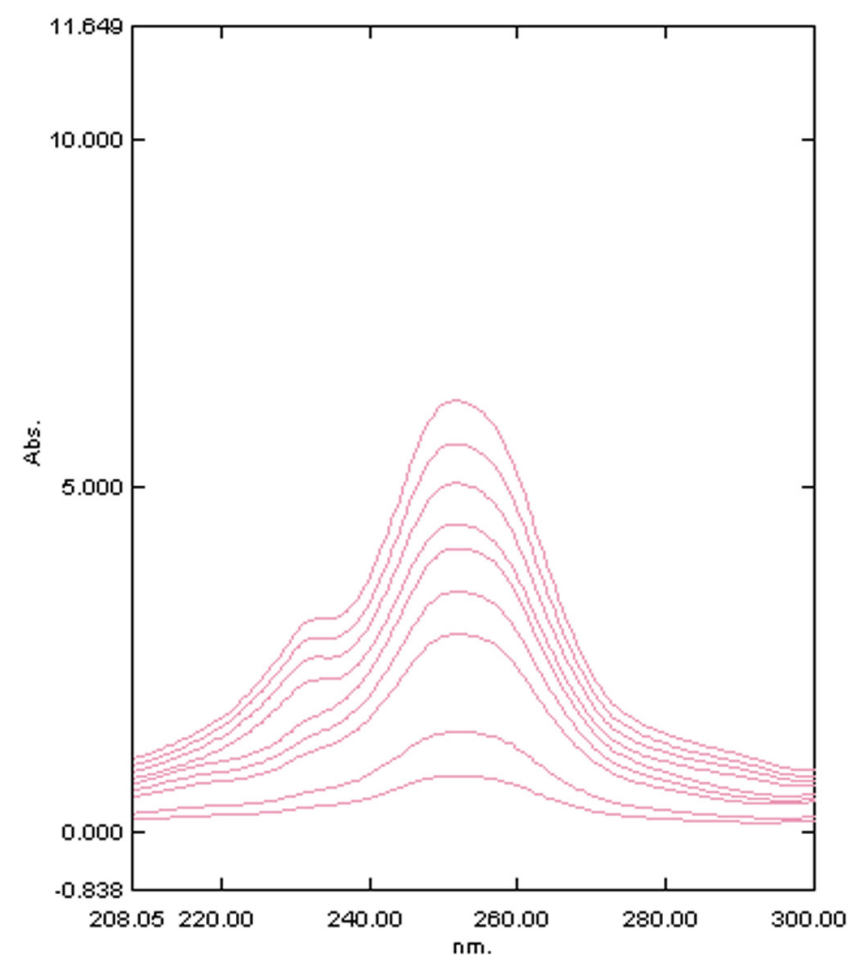

FIGURE 3 - Ratio spectra of DC by DS6.

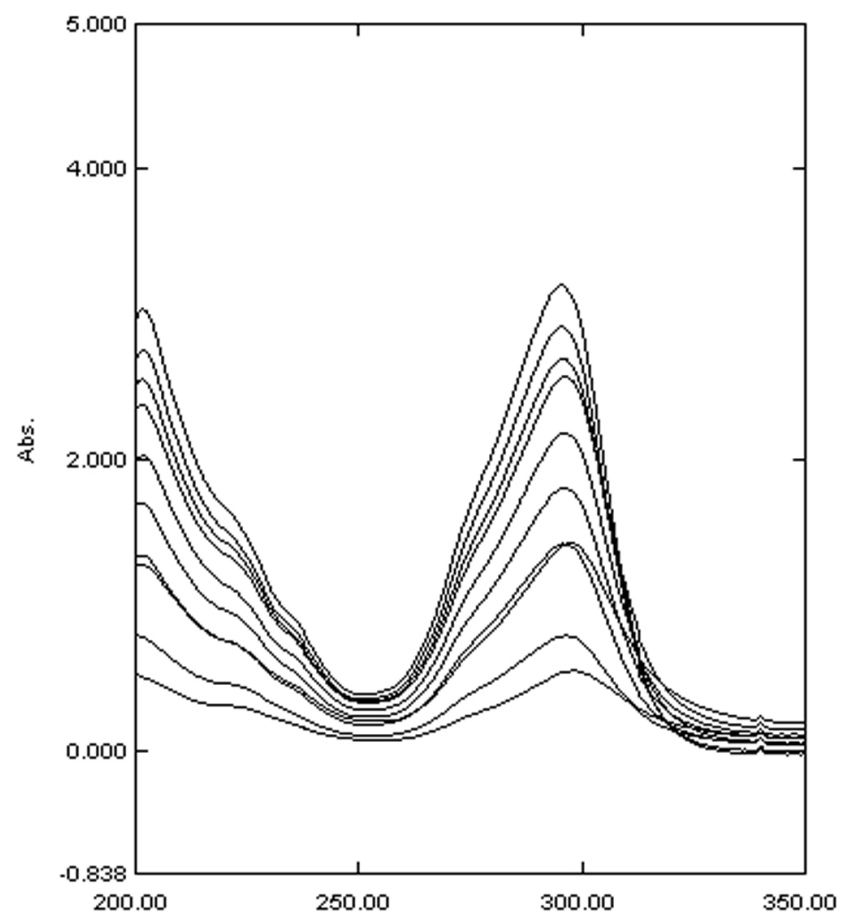

FIGURE 4 - Ratio spectra of DS by DC5. 


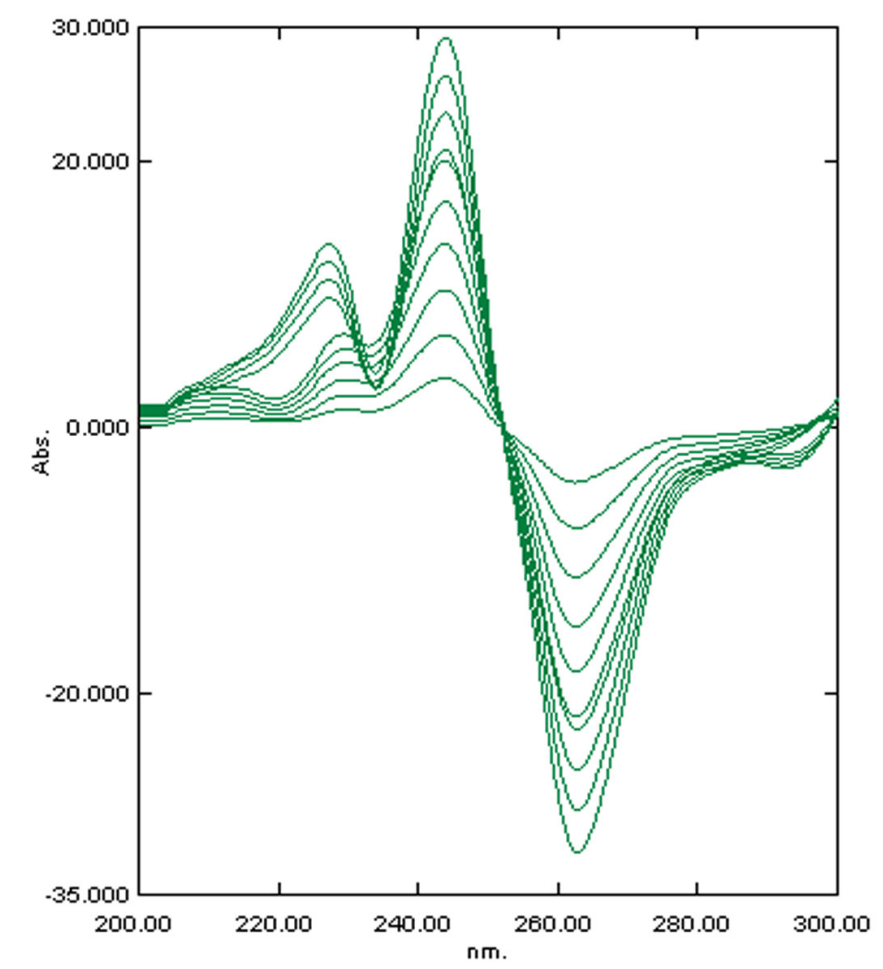

FIGURE 5 - Ratio Derivative spectra of DC.

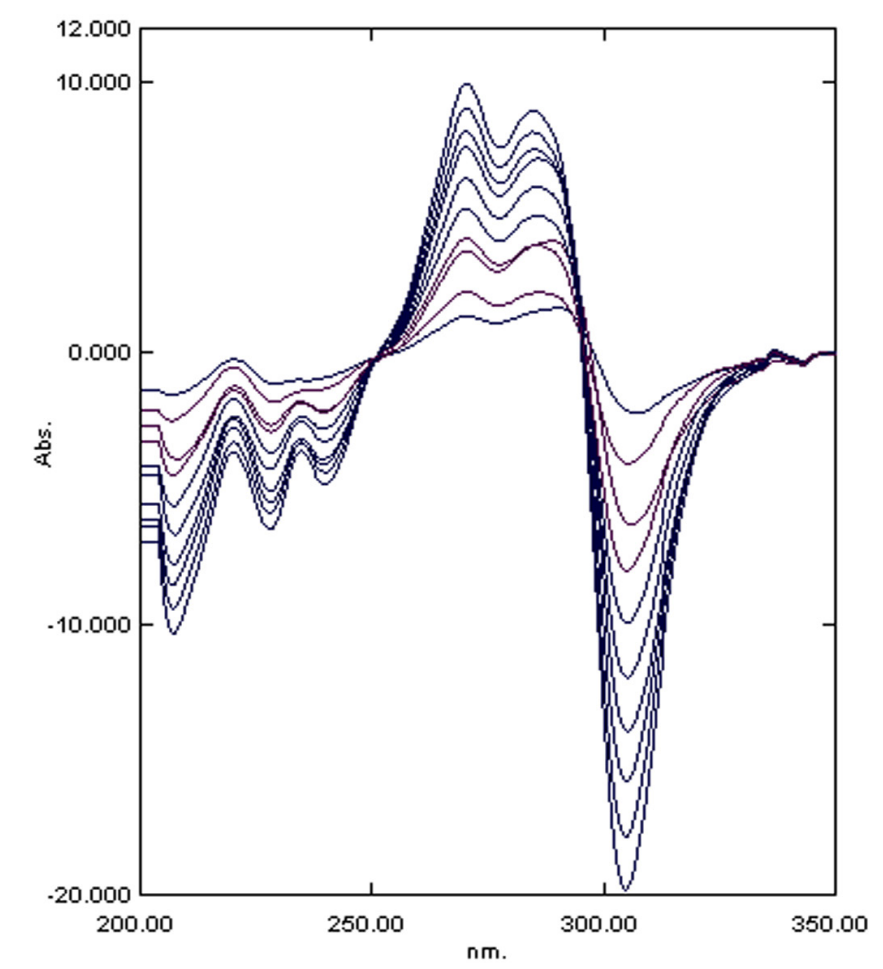

FIGURE 6 - Ratio derivative spectra of DS.

\section{LC-DAD Analysis}

In case of LC-DAD analysis the maximum for DC was observed at $257 \mathrm{~nm}$ and for DS at $274 \mathrm{~nm}$. The chromatogram was subjected to peak purity analysis in order to study any co-elution. The LC-DAD analysis revealed the peak to be pure and spectrally homogenous with peak purity angle 0.319 being less than the peak purity threshold 0.459 for DS and for DC 0.327 and 0.451 respectively. The average retention time of DC peak was $3.81 \pm 0.05$ minutes $( \pm$ S.D.; $n=3)$ and for DS was 9.22 \pm 0.11 minutes. A reasonable resolution between the DC and DS peaks was observed in the sample (Figure 7). The peaks were symmetrical and well resolved.

\section{Validation of the developed methods}

The Ratio Derivative method and liquid chromatographic method were validated as per ICH (Q2/ $\mathrm{R} 1)$ guidelines and the various parameters were evaluated, which are presented as follows.

\section{Linearity and sensitivity (LOD and LOQ)}

In case of RDS analysis the method was found to be linear in the concentration range $1-10 \mu \mathrm{g} / \mathrm{mL}$ for both DC and DS with $\mathrm{r}^{2}$ value 0.999 for DS and 0.996 for DC. The LOD and LOQ for DC were $0.361 \mu \mathrm{g} / \mathrm{ml}$ and $0.975 \mu \mathrm{g} / \mathrm{ml}$ and for DS $0.257 \mu \mathrm{g} / \mathrm{mL}$ and $0.444 \mu \mathrm{g} / \mathrm{mL}$, respectively (Millership, Parker, Donnelly, 2005).

For LC-DAD analysis the linearity concentration region was observed in the range of 5.0 to $40.0 \mu \mathrm{g} / \mathrm{mL}$. $\mathrm{An}$ area versus concentration curve was drawn with the concentration on $\mathrm{X}$ - axis and the peak area on the Y-axis. The linear regression parameters were slope 99609 and Y- intercept 99070 at $95 \%$ confidence interval $(p<0.0015)$ for DC and slope 44032 and Y- intercept 26445 at $95 \%$ confidence interval $(p<0.0011)$ for DS. The correlation coefficient $r^{2}$ was 0.999 for DC and 0.998 for DS. A statistical residual analysis was performed for each point of concentration range corresponding to the difference between the estimated and the mean concentrations. The residual plot analysis demonstrated that the residual values were randomly distributed around the zero value. This confirms the choice of linear model (Snyder, Kirkland, Glajach, 1997). The sensitivity of the method was evaluated on the basis of LOD and LOQ values which were $1.98 \mu \mathrm{g} / \mathrm{mL}$ and $6.01 \mu \mathrm{g} / \mathrm{mL}$ respectively for DS and $3.28 \mu \mathrm{g} / \mathrm{mL}$ and $9.95 \mu \mathrm{g} / \mathrm{mL}$ respectively for DC (Table I ).

\section{Precision}

For both RDS and HPLC analysis the precision of the method was analyzed on the basis of repeatability as presented in Table I. The intra-day and inter-day precision values were calculated from the linearity curve and the observed \% RSD value was $<2.0$ (Ahuja, Scrypinski, 2001; Snyder, Kirkland, Glajach, 1997) (Table I). The 

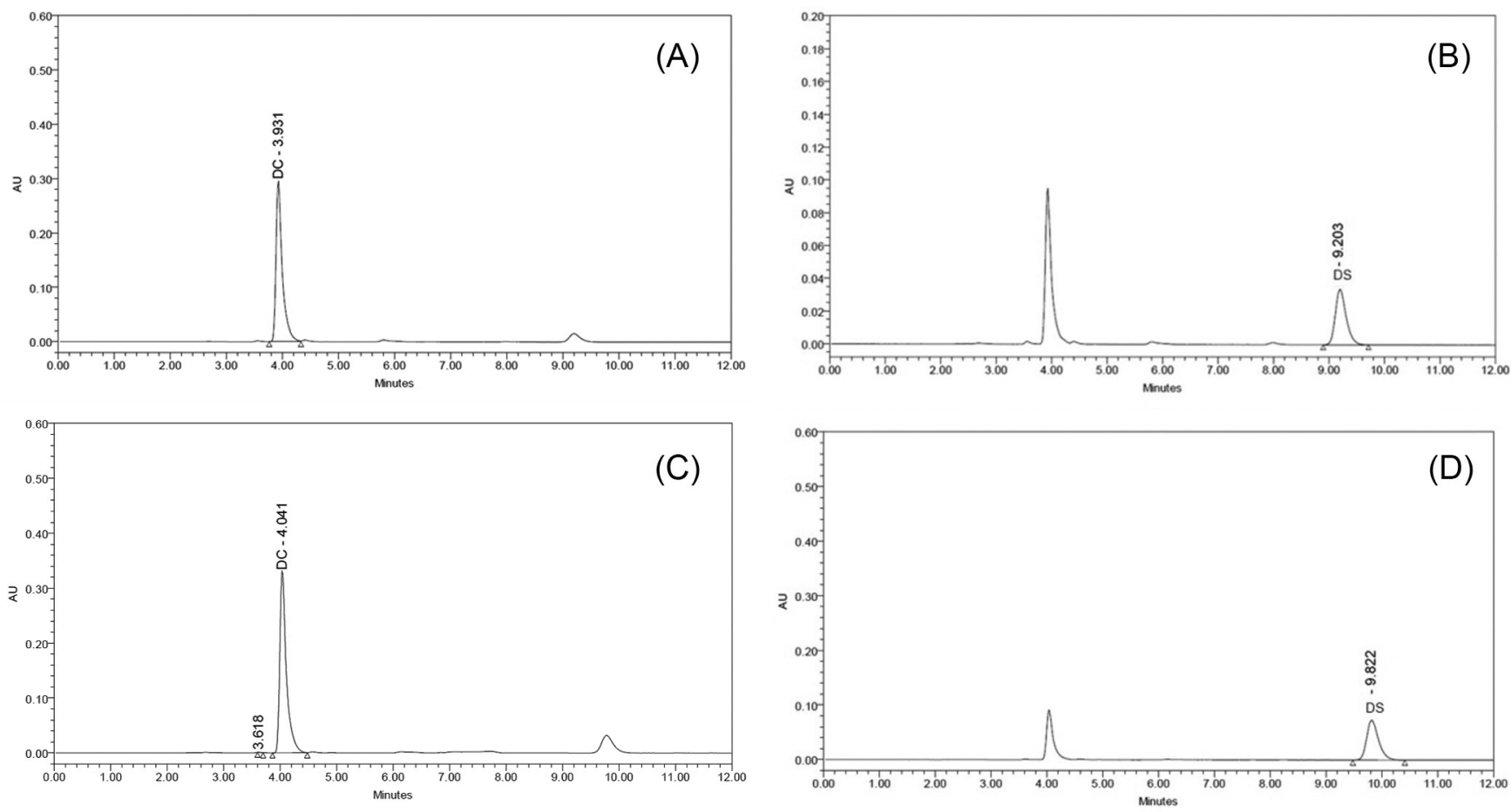

FIGURE 7 - Representative chromatograms of DC at $257 \mathrm{~nm}$ (A) and DS at $274 \mathrm{~nm}$ (B), chromatogram of DC from sample formulation (C) and DS from sample formulation (D).

obtained intra-day \% RSD values were higher than that of the inter-day values although both are in acceptable range. Therefore the results suggest that both the method is more precise in case of inter-day study than the intraday study.

\section{Accuracy}

The accuracy of a method is defined as a percentage of systematic error and was calculated as the deviation agreement between the measured value and the true value (Snyder, Kirkland, Glajach, 1997). In our study, the accuracy was determined on the basis of recovery study for both the analytical methods.

For RDS analysis RSD\% of 0.145 for DC and 0.526 for DS was observed (Table II) (Millership, Parker, Donnelly, 2005). At three different levels $-80 \%, 100 \%$ and $120 \%$. Therefore the results established a satisfactory level of accuracy.

The analysis results revealed a recovery of $99.50 \%$ to $100 \%$ with a RSD \% of 0.45 for DC and $99.00 \%$ to $101.00 \%$ for DS with RSD $\%$ of 0.90 for LC-DAD analysis (Table III). These results also ensured the accuracy of the method.

\section{Robustness}

The robustness was tested in order to evaluate the variation of analytical result due to deliberate changes in analytical conditions. The changes in operational parameters (change in person) did not lead to significant changes in the result. The response determined in the robustness test is the percentage of the drug in relation to the nominal amount of sample and the percent variation between them was $0.96 \%$ for DC and $0.95 \%$ for DS in spectroscopic analysis and $0.97 \%$ for DC and $0.98 \%$ for DS in chromatographic analysis. The results of robustness study for both the methods established their acceptability (Millership, Parker, Donnelly, 2005).

\section{Specificity}

The results obtained from both proposed methods for the placebo and the standard solutions were compared.

The specificity with regard to other co-eluting components of DC and DS were separately investigated in HPLC. Sufficient resolution between DS and DC peak were observed under optimized chromatographic conditions (Figure 7). In all cases the purity angle was less than the peak purity threshold indicating the absence of any co-eluting peaks. The resolution factor between the DC and DS peaks in the chromatogram of the sample was 4.81 (Table I).

\section{System Suitability}

System suitability study was carried out for the chromatographic analysis only. The approximate results were theoretical plates $(N=12356$ for DC and 26359 for 
TABLE I - Validation data for the estimation of DC and DS from transdermal gel preparation based on LC-DAD and Ratio derivative spectroscopic analysis

\begin{tabular}{|c|c|c|c|c|}
\hline \multirow[t]{2}{*}{ Parameters } & \multicolumn{2}{|c|}{ LC-DAD } & \multicolumn{2}{|c|}{ Ratio Derivative Spectroscopy } \\
\hline & DC & DS & DS & DC \\
\hline \multicolumn{5}{|l|}{ System suitability } \\
\hline Retention time (min) & $3.80 \pm 0.29$ & $9.20 \pm 0.69$ & - & - \\
\hline Capacity factor & 1.80 & 3.90 & - & - \\
\hline Resolution & - & 4.81 & - & - \\
\hline USP tailing factor & 0.95 & 0.01 & - & - \\
\hline $\begin{array}{l}\text { USP theoretical plates } \\
\text { (N) }\end{array}$ & 12356 & 26359 & - & - \\
\hline \multicolumn{5}{|l|}{ Sensitivity } \\
\hline $\begin{array}{l}\text { Limit of detection } \\
\text { (LOD) }(\mu \mathrm{g} / \mathrm{mL})\end{array}$ & 3.28 & 1.98 & 0.25 & 0.32 \\
\hline $\begin{array}{l}\text { Limit of quantitation } \\
(\mathrm{LOQ}(\mu \mathrm{g} / \mathrm{mL})\end{array}$ & 9.95 & 6.01 & 0.44 & 0.96 \\
\hline \multicolumn{5}{|l|}{ Precision } \\
\hline \multicolumn{5}{|l|}{ Intra-day } \\
\hline $\begin{array}{l}\text { Repeatability }(\mathrm{mg} / \mathrm{g} \text { of } \\
\text { gel) }(n=6)\end{array}$ & 19.96 & 20.07 & 20.99 & 21.05 \\
\hline$\%$ RSD & 0.98 & 0.05 & 1.43 & 1.03 \\
\hline \multicolumn{5}{|l|}{ Inter-day } \\
\hline $\begin{array}{l}\text { Mean drug content } \\
\text { (mg/g of gel) } \\
(\text { day } 1 / \text { day } 2 / \text { day } 3) \\
(\mathrm{n}=3)\end{array}$ & 19.95/19.78/19.81 & $19.99 / 20.11 / 20.15$ & 20.89/19.99/20.81 & $21.11 / 20.96 / 20.59$ \\
\hline Intermediate precision & 19.85 & 20.08 & 20.56 & 20.89 \\
\hline $\begin{array}{l}(\% \mathrm{RSD})(\text { day } 1 / \text { day } 2 / \\
\text { day } 3)(\mathrm{n}=6)\end{array}$ & $1.01 / 0.56 / 0.87$ & $0.12 / 0.09 / 0.05$ & $0.55 / 0.43 / 0.55$ & $0.52 / 0.55 / 0.68$ \\
\hline
\end{tabular}

TABLEII - Table for accuracy study DC and DS for ratio derivative spectroscopy analysis

\begin{tabular}{|c|c|c|c|c|c|c|c|c|c|c|}
\hline & $\begin{array}{c}\text { Average } \\
\text { Theoretical } \\
\text { concentration } \\
\text { of sample } \\
\text { solution } \\
(\mu \mathrm{g} / \mathrm{mL})\end{array}$ & $\begin{array}{c}\text { Solution } \\
(\%)\end{array}$ & $\begin{array}{c}\text { Theoretical } \\
\text { Concentration } \\
\text { from spiked } \\
\text { solution } \\
(\mu \mathrm{g} / \mathrm{mL})\end{array}$ & $\begin{array}{c}\text { Theoretical } \\
\text { excess } \\
\text { amount } \\
\text { added } \\
(\mu \mathrm{g} / \mathrm{mL})\end{array}$ & $\begin{array}{c}\text { Average } \\
\text { actual } \\
\text { assay from } \\
\text { sample } \\
\text { solution } \\
(\mu \mathrm{g} / \mathrm{mL})\end{array}$ & $\begin{array}{c}\text { Assay from } \\
\text { spiked } \\
\text { solution } \\
(\mu \mathrm{g} / \mathrm{mL})\end{array}$ & $\begin{array}{c}\text { Observed } \\
\text { excess } \\
\text { amount } \\
(\mu \mathrm{g} / \mathrm{mL})\end{array}$ & $\begin{array}{c}\text { Recovery } \\
\text { differrence } \\
(\mu \mathrm{g} / \mathrm{mL})\end{array}$ & $\begin{array}{c}\text { Accuracy } \\
(\%)\end{array}$ & $\%$ RSD \\
\hline & 19.99 & 120 & 23.99 & 4.00 & 20.14 & 23.92 & 4.21 & 0.21 & 99.74 & 0.145 \\
\hline \multirow[b]{2}{*}{$\mathrm{DS}$} & \multirow[b]{2}{*}{20.01} & 80.0 & 16.01 & 4.00 & \multirow[b]{2}{*}{20.03} & 15.76 & 4.27 & 0.27 & 98.45 & \multirow[b]{2}{*}{0.526} \\
\hline & & 100 & 22.01 & 2.00 & & 21.89 & 2.14 & 0.14 & 99.50 & \\
\hline
\end{tabular}


TABLEIII - Table for accuracy study DC and DS for chromatographic analysis

\begin{tabular}{|c|c|c|c|c|c|c|c|c|c|c|}
\hline & $\begin{array}{c}\text { Average } \\
\text { Theoretical } \\
\text { concentration } \\
\text { of sample } \\
\text { solution } \\
(\mu \mathrm{g} / \mathrm{mL}) \\
\end{array}$ & Solution & $\begin{array}{l}\text { Theoretical } \\
\text { concentration } \\
\text { from spiked } \\
\text { solution } \\
(\mu \mathrm{g} / \mathrm{mL})\end{array}$ & $\begin{array}{c}\text { Theoretical } \\
\text { excess } \\
\text { amount } \\
\text { added } \\
(\mu \mathrm{g} / \mathrm{mL})\end{array}$ & $\begin{array}{c}\text { Average } \\
\text { actual assay } \\
\text { from sample } \\
\text { solution } \\
(\mu \mathrm{g} / \mathrm{mL})\end{array}$ & $\begin{array}{c}\text { Assay from } \\
\text { spiked } \\
\text { solution } \\
(\mu \mathrm{g} / \mathrm{mL})\end{array}$ & $\begin{array}{c}\text { Observed } \\
\text { excess } \\
\text { amount } \\
(\mu \mathrm{g} / \mathrm{mL})\end{array}$ & $\begin{array}{c}\text { Recovery } \\
\text { difference } \\
(\mu \mathrm{g} / \mathrm{mL})\end{array}$ & $\begin{array}{c}\text { Accuracy } \\
(\%)\end{array}$ & $\%$ RSD \\
\hline \multirow{3}{*}{$\mathrm{DC}$} & \multirow{3}{*}{19.99} & $80.0 \%$ & 15.99 & 4.00 & \multirow{3}{*}{19.96} & 15.91 & 4.05 & 0.05 & 99.50 & \multirow{3}{*}{0.45} \\
\hline & & $100 \%$ & 21.99 & 2.00 & & 21.96 & 2.00 & 0.00 & 100.00 & \\
\hline & & $120 \%$ & 23.99 & 4.00 & & 23.92 & 3.96 & 0.04 & 99.71 & \\
\hline \multirow{3}{*}{ DS } & \multirow{3}{*}{20.01} & $80.0 \%$ & 16.01 & 4.00 & \multirow{3}{*}{20.07} & 16.03 & 4.04 & 0.04 & 101.00 & \multirow{3}{*}{0.90} \\
\hline & & $100 \%$ & 22.01 & 2.00 & & 22.05 & 1.98 & 0.02 & 99.00 & \\
\hline & & $120 \%$ & 24.01 & 4.00 & & 24.07 & 4.00 & 0.00 & 100.00 & \\
\hline
\end{tabular}

DS), capacity factor ( $k=1.80$ for DC and 3.90 for DS), peak asymmetry or tailing factor $(t=0.95$ for DC and 0.01 for DS). The values for these parameters were satisfactory in accordance with the literature (Snyder, Kirkland, Glajach, 1997) (Table I).

\section{Solution stability}

The prepared solution was evaluated after 7 days and found to be stable only when kept at $4{ }^{\circ} \mathrm{C}$.

\section{Comparison between UV and HPLC method}

Both proposed analytical techniques were compared using statistical analysis.

The $F$-test was applied to determine whether one population is more variable than another in relative standard deviations (repeatability). Referring to the table of $F$ against 1 degree of freedom (d.f) for between mean square and 16 d.f for within mean square, we find a value 4.49 at $5 \%$ level of significance. Since the value 1.0003 for $\mathrm{F}$ obtained in the present experiment which is far below than the recorded value 4.49 , we conclude that the difference between the methods is highly insignificant $(\mathrm{p}>0.05)$.

The $t$-test was applied to determine whether or not there is a statistically significant difference between the mean assay values of two proposed methods. The obtained results were 0.917 and 1.59 , for DC and DS respectively, well below the tabled value (2.776) at 95\% confidence level.

The calculated $F$-values and $t$-values were found to be less than the critical values at $5 \%$ significance level (4.49 and 2.776 respectively).

The LOD and LOQ values for both methods suggested that the RDS method was more sensitive than
LC-DAD method. But the regression values helped to predict the determination of DC more accurately by LCDAD analytical method whereas DS was determined more accurately by RDS method. The RDS technique is simpler, economic, need lesser time and sufficient samples can be done within a day compared to LC-DAD method. But LC-DAD analysis method was more precise, specific and robust than the RDS method.

Therefore the study represented the fact that the RDS method was more accurate and sensitive whereas the LC-DAD analysis was more precise. So, the RDS method and the chromatographic method can be claimed as unique and novel approach for the simultaneous determination of these two drugs in a combined dosage form. Thus the developed new methods will definitely help in analysis of this combined drug product.

\section{CONCLUSION}

The study presents two simple, selective and sensitive methods for the quantification of both Diacerein and Diclofenac sodium from their combined dosage form. The reliability of the methods is reflected from the validation parameters. Statistical studies revealed that there were no significant differences among the proposed methods. However, it appears that the ratio derivative spectrophotometric method is more simple, economic and accurate compared to the chromatographic method although a higher precision can be observed in the latter method.

\section{ACKNOWLEDGEMENTS}

Kind acknowledgements to University of Calcutta for providing facility for carry out the work. The authors 
also acknowledge the invaluable support of Prof. (Dr.) Arup Mukherjee for the successful completion of the work. The authors also thank Dey's Medical Stores (Mfg.) Ltd. for their invaluable support and providing diclofenac sodium sample.

\section{CONFLICT OF INTEREST}

The authors disclose no conflict of interests.

\section{REFERENCES}

ABDEL-HAMID, M.E.; NOVOTNY, L.; HAMZA, H. Determination of Diclofenac sodium, flufenamic acid, indomethacin and Ketoprofen by LC-APCI-MS. J. Pharm. Biomed. Anal., v.24, n.4, p.587-594, 2001.

AHUJA, S.; SCRYPINSKI, S. Hand book of modern pharmaceutical analysis. Amsterdam: Academic press, 2001. p.415-442.

ALI, N.W.; ABDELWAHAB, N.S.; ABDELKAWY, M.; EMAM, A.A. Validated stability indicating TLCdensitometric method for the determination of diacerein. J. Chromatogr. Sci., v.52, n.1, p.5-11, 2014.

ASHOK, C.; GOLAK, M.; ADWAIT, D.; KRISHNA, V.; HIMANI, A.; UMESH, P.; AMOL, G.; SRINIVAS, S.; SHARAD, M.; DEEPALI, J.; ATUL, C. Isolation and structural elucidation of two impurities from adiacereinbulk drug. J. Pharm. Biomed. Anal., v.49, n.2, p.525-528, 2009.

BAGHEL, U.S.; DHIMAN, V. Exploring the application of hydrotropic solubilization phenomenon for estimating diacerein in capsule dosage form by spectrophotometry methods. Asian Pac. J. Trop. Biomed., v.2, p.S1720-S1727, 2012.

BARTELSYZ, E.M.; BLIDDALYX, H.; SCHONDORFFY, P.K.; ALTMANK, R.D.; ZHANG, W.; CHRISTENSENY, R. Symptomatic efficacy and safety of diacerein in the treatment of osteoarthritis: a meta-analysis of randomized placebo-controlled trials. Osteoarthritis Cartilage, v.18, n.3, p.289-296, 2010.

BOTELLO, J.C.; PEREZ-CABALLERO, G. Spectrophotometric determination of diclofenac sodium with methylene blue. Talanta, v.42, n.1, p.105-108, 1995.
CARREIRA, L.A.; RIZK, M.; EL-SHABRAWY,Y.;ZAKHARI, N.A.; TOUBAR, S.S. Europium(III)ion probe spectro fluorometric determination of diclofenac sodium. J. Pharm. Biomed. Anal., v.13, n.11, p.1331-1337, 1995.

DAHIVELKAR, P.P.; BHOIR, S.I.; BARI, S.B.; SURANA, S.J.; BHAGWAT, A.M. Simultaneous determination of diclofenac potassium and drotaverine hydrochloride in human plasma using reversed-phase high-performance liquid chromatography. J. Chromatogr Sci., v.50, n.8, p.694-701, 2012.

FIDELIX, T.S.; MACEDO, C.R.; MAXWELL, L.J.; FERNANDES, M.T.V. Diacerein for osteoarthritis. Coch. Database Syst. Rev., n.1, CD005117, 2014.

GADOTTI, V.M.; MARTINS, D.F.; PINTO, H.F.; OLIVEIRA, G.; KASTER, M.P.; QUINTAO, N.L.; SANTOS, A.R. Diacerein decreases visceral pain through inhibition of glutamatergic neurotransmission and cytokine signaling in mice. Pharmacol. Biochem. Behav., v.102, n.4, p.549-554, 2012.

HAMRAPURKAR, P.; PATIL, P.; DESAI, M.; PHALE, M.; PAWAR, S. Stress degradation studies and development of a validated stability-indicating-assay-method for determination of diacerein in presence of degradation products. Pharm. Meth., v.2, n.1, p.30-35, 2011.

JI, W.; ZHAN, J. Determination of diclofenac sodium by capillary zone electrophoresis with electrochemical detection. J. Chromatogr. A., v. 868, n.1, p.101-107, 2000.

KAALE, E.; NYAMWERU, B.C.; MANYANGA, V.; CHAMBUSO, M.; LAYLOFF, T. The development and validation of a Thin Layer Chromatography densitometry method for the analysis of diclofenac sodium tablets. Int. J. Chem. Anal. Sci., v.4, n.1, p.73-79, 2013.

KARADE, P.G.; SHAH, R.R.; CHOUGULE, D.D.; BHISE, S.B. Formulation and Evaluation of Celecoxib Gel. J. Drug Deliv. Therap., v.2, n.3, p.132-135, 2012.

L O U T H R EN O O, W. ; N I L G A N U W ON G, S .; AKSARANUGRAHA, S.; ASAVATANBODEE, P.; SAENGNIPANTHKUL, S. The efficacy, safety and carry-over effect of diacerein in the treatment of painful knee osteoarthritis: a randomised, double-blind, NSAIDcontrolled study. Osteoarthritis Cartilage, v.15, n.6, p.605614, 2007. 
MILLERSHIP, J.S.; PARKER, C.; DONNELLY, D. Ratio spectra derivative spectrophotometry for the determination of furosemide and spironolactone in capsule formulation. Farmaco, v.60, n.4, p.333-338, 2005.

NEBSEN, M.; ABDEL-RAHMAN, M.K.; SALEM, M.Y.; ELKOSASY, A.M.; EL-BARDICY, M.G. Stability-indicating spectrophotometric and spectrodensitometric methods for the determination of diacerein in the presence of its degradation product. Drug Test Anal., v.3, n.4, p.221-227, 2011.

OJHA A.; RATHOD, R.; PADH, H. Simultaneous HPLC-UV determination of rhein and aceclofenac in human plasma. $J$. Chromatogr. B, v.877, n.11-12, p.1145-1148, 2009.

PANDEY, R.; PATIL, P.O.; PATIL, M.U.; DESHMUKH, P.K.; BARI, S.B. Quantitative estimation of diacerein in bulk and in capsule formulation using hydrotropic solubilizing agents by UV-spectrophotometry and the first order derivative using the area under curve method. Pharm. Meth., v.3, n.1, p.4-8, 2012.

PATEL, N.S.; NANDURBARTKAR, V.P.; PATEL, A.J.; PATEL, S.G. Simultaneous spectrophotometric determination of celecoxib and diacerein in bulk and capsule by absorption correction method and chemometric methods. Spectrochim. Acta A: Mol. Biomol. Spectrosc., v.125, p.46-52, 2014.

PELLETIER, J.P.; MARTEL-PELLETIER, J. DMOAD developments: present and future. Bull. NYU Hosp. Jt. Dis., v.65, n.3, p.242-248, 2007.

ROTE, A.R.; BARI, P.D. Ratio spectra derivative and zerocrossing difference spectrophotometric determination of olmesartan medoxomil and hydrochlorothiazide in combined pharmaceutical dosage form. AAPS PharmSciTech., v.10, n.4, p.1200-1205, 2009.

SINGH, K.; SHARMA, R.; RAI, J. Diacerein as adjuvant to diclofenac sodium in osteoarthritis knee. Int. J. Rheum. Dis., v.15, n.1, p.69-77, 2012.
SIVAKUMAR, R.; NALLASIVAN, P.; SARANYA, K.; SAM, S.W.; AKELESH, T.; VENKATNARAYANAN, R. Visible spectrophotometric estimation of diacerein in bulk and pharmaceutical dosage forms. J. Young Pharm., v.2, n.4, p.414-416, 2010.

SNYDER, R.L.; KIRKLAND, J.; GLAJACH, L. Pratical HPLC method development. Hoboken, NY, USA: JonhWiley \& Sons, 1997. p.643-645.

TAMURA, T.; SHIRAI, T.; KOSAKA, N.; OHMORI, K.; TAKAFUMI, N. Pharmacological studies of diacerein in animal models of inflammation, arthritis and bone resorption. Eur. J. Pharmacol., v.448, p.81-87, 2002.

THONGCHAI, W.; LIAWRUANGRATH, B.; THONGPOON, C.; THEERAPHAN, M. High performance thin layer chromatographic method for the determination of diclofenac sodium in pharmaceutical formulations. Chiang Mai J. Sci., v.33, n.1, p.123-128, 2006.

VERBRUGGEN, G. Chondroprotective drugs in degenerative joint diseases. Rheumatol., v.45, p.129-138, 2006.

ZHANG, Y.; CUN, D.; KONG, X.; FANG, L. Design and evaluation of a novel transdermal patch containing diclofenac and teriflunomide for rheumatoid arthritis therapy. Asian J. Pharm. Sci., v.9, p.251-259, 2014.

ZHENG, W.J.; TANG, F.L.; LI, J.; ZHANG, F.C.; LI, Z.G.; SU, Y.; WU, D.H.; MA, L.; ZHOU, H.Q.; HUANG, F.; ZHANG, J.L.; LIANG, D.F.; ZHOU, Y.X.; XU, H. Evaluation of efficacy and safety of diacerein in knee osteoarthritis in Chinese patients. Chin. Med. Sci. J., v.21, n.2, p.75-80, 2006.

Received for publication on $05^{\text {th }}$ August 2015 Accepted for publication on $19^{\text {th }}$ December 2016 